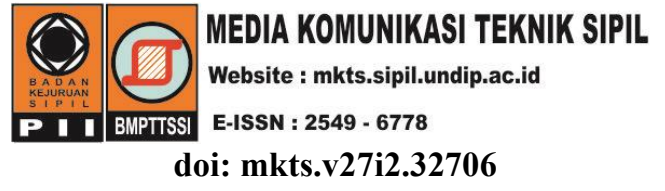

\title{
The Effect of Sodium Hydroxide Molarity on the Compressive and Splitting Tensile Strength of Ferronickel Slag-Based Alkali Activated Mortar
}

\author{
Albert Kuncoro, "Herry Suryadi Djayaprabha \\ Faculty of Engineering, Parahyangan Catholic University, Bandung \\ ${ }^{*}$ herry.suryadi@unpar.ac.id
}

Received: 5 September 2020 Revised: 29 November 2021 Accepted: 30 November 2021

\begin{abstract}
The use of cement as the main binding agent in construction contributes approximately 7-10\% in total of carbon dioxide gas emissions worldwide. In this study, the replacement of Portland cement using ground granulated ferronickel slag (GFNS) activated by the combination of sodium hydroxide (NaOH) dan sodium silicate $\left(\mathrm{Na}_{2} \mathrm{SiO}_{3}\right)$ was utilized for producing alkali-activated mortar (AAM) as construction material. Four different mortar mixtures were prepared in this experimental work. There were three mixtures of ferronickel slag-based alkali activated mortar (FAM) with the variations of $\mathrm{NaOH}$ molarity of 6, 8, and $10 \mathrm{M}$ and cementbased mortar mixture (PCM) with water-to-cement ratio (w/c) of 0.5 was used as the control specimens. Overall, the flow and workability of the FAM specimen was lower than the PCM specimen due to the presence of silicate caused a sticky characteristic on the paste. On the other hand, the unit weight of FAM mortar was higher than the PCM specimen. Among all FAM mixtures, the most effective compressive strength and splitting tensile strength results were achieved by the FAM8 mixture, with a compressive strength at 28 days of 33.72 $\mathrm{MPa}$ and the splitting tensile strength at 28 days of $2.65 \mathrm{MPa}$, which had both good workability and chemical reaction of the material.
\end{abstract}

Keywords: Alkali activated material, slag, ferronickel slag, compressive strength, splitting tensile strength

\begin{abstract}
Abstrak
Penggunaan semen hidrolis sebagai bahan pengikat dalam dunia konstruksi menyumbangkan sekitar 7-10\% emisi karbon dioksia di dunia. Pada penelitian ini, bahan pengikat berbahan dasar semen digantikan dengan bahan pengikat berbahan dasar slag feronikel halus yang diaktifkan dengan kombinasi sodium hidroksida $(\mathrm{NaOH})$ dan sodium silikat $\left(\mathrm{Na}_{2} \mathrm{SiO}_{3}\right)$ untuk membuat alkali-activated mortar (AAM) sebagai material konstruksi. Empat buah campuran mortar dipersiapkan pada studi eksperimental ini. Tiga campuran merupakan mortar berbahan dasar slag feronikel halus (FAM) dengan variasi molaritas NaOH sebesar 6M, $8 M$, dan 10M dan mortar kontrol berbahan dasar semen (PCM) dengan rasio air semen (w/c) sebesar 0,5. Secara keseluruhan, kelecakan dari campuran FAM lebih rendah daripada campuran PCM, akibat dari adanya silikat pada AAM yang menyebabkan karakteristik lengket pada bahan pengikat. Di sisi lain, berat isi benda uji mortar FAM lebih tinggi dari pada benda uji PCM. Di antara semua campuran FAM, kuat tekan dan kuat tarik belah yang paling efektif dicapai oleh benda uji FAM8, dengan kuat tekan pada hari ke-28 sebesar 33,72 MPa dan kuat tarik belah pada hari ke-28 sebesar 2,65 MPa, yang memiliki kelecakan dan reaksi kimia bahan yang baik.
\end{abstract}

Kata kunci: Alkali-activated material, slag, slag feronikel, kuat tekan, kuat tarik belah

\section{Introduction}

Construction industry is considered as the most energy intensive sectors worldwide, due to the high demand of cement and concrete. In the cement industry, combustion at the elevated temperature, cooling, controlling the chemical composition, and grinding the cement clinker are the processes that utilize a huge amount of energy (Hewlett \& Liska, 2019). Because the cement manufacturing process 
releases enormous amounts of carbon dioxide $\left(\mathrm{CO}_{2}\right)$ gas, contributing approximately $7-10 \%$ in total of carbon gas emissions worldwide, many efforts have been made to minimize the emissions. Not only reducing the energy consumption during the cement production processes, but also the efforts to find cement replacement (Chen et al., 2020). As the construction technology develops, some efforts were carried out for utilizing the industrial waste by-product as a cement replacement. The usage of pozzolanic material, such as fly ash and ground granulated blast furnace slag to produce alkali activated material have been performed by using a combination of sodium silicate $\left(\mathrm{Na}_{2} \mathrm{SiO}_{3}\right)$ and sodium hydroxide $(\mathrm{NaOH})$ as an alkaline activator (Fang et al., 2018; Puertas et al., 2018). Alkali activated material has a wide variety of potential applications in the field of construction includes: thermal insulation, fire resistant materials, low energy ceramic tiles, composites for infrastructures repair and strengthening, etc (Davidovits, 2011; Yan et al., 2021).

In the last two decades, alkali-activated materials have attracted the attention of researchers from all over the world, due to their advantages of high strength, low energy cost, and high durability when compared to Portland cement (Alnahhal et al., 2021; Shi et al., 2006). Alkali activated material is made from aluminosilicate and requires an alkaline element to be hardened.

The use of alkali-activator in the alkali-activated material greatly affects the properties of hardened sample produced. The use of strong alkali with high reaction temperature (more than $60^{\circ} \mathrm{C}$ ) is widely used because it generally produces concrete with better compressive strength (Yan et al., 2021). In the chemical reactions that occur in alkali-activated material, the alkaline solution plays a very important role. The concentration and volume of the alkaline solution used greatly influence the chemical reaction and physical properties of the specimen (Zhang et al., 2020). The ratio of $\mathrm{Na}_{2} \mathrm{SiO}_{3}$ to $\mathrm{NaOH}$ solution greatly influenced the workability of the fresh and hardened paste. The workability of alkali activated material was found decreasing with the increase of $\mathrm{Na}_{2} \mathrm{SiO}_{3}$ to $\mathrm{NaOH}$ ratio because of the chemical reaction and increment of viscosity (Kuri et al., 2021).

Ferronickel slag is an industrial waste by-product from stainless steel and nickel alloy manufactures during the smelting process of nickel ore. Nickel is produced by melting the nickel ore. the nickel ore can be melted by putting it in a hot furnace which has a temperature of about $1500-1600^{\circ} \mathrm{C}$. Melted nickel and its slag then tapped separately from the furnace with different holes. This is possible because the melted nickel and slag do not mix, and melted nickel is denser than slag (Saha et al., 2018). The waste amount of ferronickel slag keeps accumulating steadily in Indonesia, due to each refining process of one ton of nickel generates about 50 times of solid waste or equivalent to 50 tons (Sugiri, 2005). Without any special treatment, million tonnes of ferronickel slag just being disposed to a valley as land-filling. Some studies showed that the ferronickel slag powder could be utilized as a cement replacement (Chen et al., 2020; Huang et al., 2017; Kim et al., 2019) as well as to manufacture alkali activated material (Komnitsas et al., 2019). The potential use of Ground granulated ferronickel slag (GFNS) as a fine aggregate and binder in geopolymer concretes and portland cement can improve the strength and durability properties of the concrete (Saha et al., 2018).

The aim of this study is to reduce environmental pollution and massive energy consumption caused by cement manufacturing process with developing an environmentally friendly material as cement replacement. Ground granulated ferronickel slag (GFNS) was utilized for producing alkali-activated mortar (AAM) as construction material and proved to have excellent properties. Therefore, this study seeks the fresh and hardened properties of ferronickel slag-based alkali activated mortar (FAM) specimens produced by GFNS activated with $\mathrm{Na}_{2} \mathrm{SiO}_{3}$ and $\mathrm{NaOH}$ with different molarity of $6 \mathrm{M}, 8 \mathrm{M}$, and $10 \mathrm{M}$. The influence of $\mathrm{NaOH}$ molarity with respect to the workability, unit weight, compressive strength and splitting tensile strength were investigated. In addition, the equations to relate between compressive strength and splitting tensile strength of FAM were proposed in this study.

\section{Materials and Test Methods}

\section{Raw materials}

GFNS used in this study was supplied by PT. Growth Java Industry with specific gravity of 2.80 as shown in Figure 1. GFNS generally has a high content of calcium oxide $(\mathrm{CaO})$, magnesium oxide $(\mathrm{MgO})$, silicon $\left(\mathrm{SiO}_{2}\right)$, and aluminum oxide $\left(\mathrm{Al}_{2} \mathrm{O}_{3}\right)$ with chemical compositions as tabulated in Table 1.

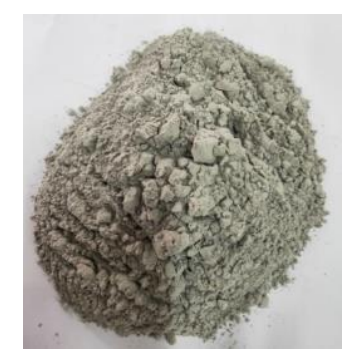

Figure 1. Ground granulated ferronickel slag 
The cement used in this study was Portland Composite Cement (PCC) that commonly found in Indonesia with inorganic ingredients of total mass in the range between $6 \%$ and $35 \%$ according to SNI 15-7064-2004 (SNI, 2004). PCC has a low to medium hydration heat during the hydration process (Susanto et al., 2019). The PCC with specific gravity of 3.050 used in this experimental study was manufactured by PT. Indocement Tunggal Prakarsa, Tbk. The fine aggregates used in this study were natural mountain sand obtained from sand mining at the foot of the Galunggung mountain in West Java, Indonesia. Fine aggregates were washed and oven dried at temperature $110 \pm 5^{\circ} \mathrm{C}$ for $24 \mathrm{~h}$ before being used. The fine aggregates used had specific gravity of 2.425 and absorption of $2.97 \%$.

Table 1. Chemical compositions of GFNS

\begin{tabular}{lc}
\hline Parameters & Value (wt\%) \\
\hline $\mathrm{Ni}$ & 0.09 \\
$\mathrm{CO}$ & 0.02 \\
$\mathrm{Fe}$ & 2.24 \\
$\mathrm{Fe}_{2} \mathrm{SO}_{3}$ & 3.20 \\
$\mathrm{CaO}$ & 24.83 \\
$\mathrm{MgO}$ & 18.81 \\
$\mathrm{Na}_{2} \mathrm{O}$ & 0.44 \\
$\mathrm{Al}_{2} \mathrm{O}_{3}$ & 6.23 \\
$\mathrm{SiO}_{2}$ & 40.69 \\
$\mathrm{P}_{2} \mathrm{O}_{5}$ & 0.21 \\
$\mathrm{SO}_{3}$ & 0.37 \\
$\mathrm{~K}_{2} \mathrm{O}$ & 0.24 \\
$\mathrm{TiO}_{2}$ & 0.19 \\
$\mathrm{Cr}_{\mathrm{Cr}} \mathrm{O}_{3}$ & 0.68 \\
$\mathrm{MnO}_{\mathrm{Lost}}$ of ignition & 0.99 \\
\hline
\end{tabular}

\section{Alkaline activators}

In this study, alkaline solutions used were sodium silicate $\left(\mathrm{Na}_{2} \mathrm{SiO}_{3}\right)$ and $\mathrm{NaOH}$. Both solutions were combined and used to achieve good compressive strength and workability (Yang et al., 2012). In addition, those chemicals are widely available in Indonesia. $\mathrm{Na}_{2} \mathrm{SiO}_{3}$ was obtained from PT. Brataco (Bratachem). $\mathrm{NaOH}$ is one of the substances that is easily produced in the chemical industry, because it only requires soda ash and sulfuric acid. Caustic soda solids are obtained by cooling down the molten caustic soda, where all of the water has evaporated inside the metal drum (Shi et al., 2006). Sodium hydroxide solution was obtained from the dissolution of sodium hydroxide flakes with distilled water. The mass of the required flakes was weighed according to the targeted concentration, then dissolved with distilled water in a volumetric flask, then the water was added until the total volume of the solution reached $1 \mathrm{~L}$. One key factor affecting the physical properties of specimen is the concentration of the alkali liquid.

Sodium silicate is an alkaline solution that is easily available, inexpensive, and commonly used in the soap industry. It is manufactured by melting primary sand and sodium carbonate (Shi et al., 2006). The specific gravity of each solution was measured with a $25 \mathrm{~mL}$ laboratory pycnometer. Specific gravities of sodium hydroxide solutions were $1.348,1.412$, and 1.471 for the concentration of $6 \mathrm{M}, 8 \mathrm{M}$, and $10 \mathrm{M}$ respectively. Whereas, the specific gravity of sodium silicate was 1.718 .

\section{Mixture proportions}

Four different mortar mixtures were prepared in this experimental work. There were three mixtures of ferronickel slag-based alkali activated mortar (FAM) with the variations of $\mathrm{NaOH}$ molarity of 6 , 8 , and $10 \mathrm{M}$ and cement-based mortar mixture (PCM) with water-to-cement ratio (w/c) of 0.5 was used as the control specimens as shown in Table 2. The alkali liquid-to-binder ratio (AL/B) of FAM mixtures was fixed by 0.5 . The fine aggregate-tobinder ratio was fixed by 2.5 . The mixture proportions were calculated by using volumetric method.

\section{Specimens, casting process, and curing}

The 50-mm cubic specimens were manufactured for investigating the unit weight and compressive strength of hardened mortar specimen. The small

Table 2. Mixture Proportions $\left(\mathrm{kg} / \mathrm{m}^{3}\right)$

\begin{tabular}{lcccccc}
\hline \multicolumn{1}{c}{ Code } & FS & SH & SS & C & W & FA \\
\hline FAM6 & 596 & 81 & 202 & - & - & 1491 \\
FAM8 & 597 & 82 & 205 & - & - & 1492 \\
FAM10 & 598 & 82 & 206 & - & - & 1495 \\
PCM & - & - & - & 538 & 309 & 1345 \\
\hline
\end{tabular}

FAM = ferronickel slag alkali activated mortar, the numbers denote the molarity. PCM = portland cement composite mortar with $\mathrm{w} / \mathrm{c}=0.5, \mathrm{FS}=$ ferronickel slag, $\mathrm{SH}=$ sodium hydroxide, $\mathrm{SS}=$ sodium silicate, $\mathrm{C}=$ cement, $\mathrm{W}=$ water, $\mathrm{FA}$ = fine aggregate 
cylindrical specimens with $50 \mathrm{~mm}$ in diameter and $100 \mathrm{~mm}$ in height, which has been used popularly used for determining hardened mortar splitting tensile strength (Çomak et al., 2018; Wang \& Meyer, 2012), were prepared in this study. The procedure of casting mortar specimens is carried out in the following steps. First, prepare all the materials and equipment that used in the mixing process. Pour the GFNS into the mixing bowl and start the mixer, then the alkaline solution was added into the mixer gradually. The mixer was continuously running until for two minutes to allow GFNS reacts with the alkaline solution and it evenly mixed. Then the fine aggregate was put into the mixture for another three minutes until the mixture is evenly distributed. Immediately after that, the fresh mortar was poured into the mold in two layers, each layer was tamped with the procedure in ASTM C109 (ASTM, 2020). After the surface of mortar specimens were flattened, then the fresh mortar specimens were covered by plastic wrapping to minimize evaporation. One day after casting, the mortar specimens were demolded and sealed cured in a standard room temperature $\left(22 \pm 2^{\circ} \mathrm{C}\right)$ until the day of testing.

\section{Test on fresh mortar}

The flow table apparatus, according to ASTM C230 (ASTM, 2014), has been widely used for characterizing the workability of hydraulic cement mortar. The workability of fresh mortar is very important, because it defines how easily the material is mixed, compacted, and then molded. The flow test was carried out according to ASTM C1437 (ASTM, 2015). The fresh mortar was placed in the mold in two layers. After tamping 20 times each layer, the mold was removed then the flow table was turned on for dropping the table 25 times. Immediately after that, the fresh mortar diameter was measured four times and the average diameter $\left(D_{\text {avg }}\right)$ was calculated.

\section{Tests on hardened mortar}

Compressive strength tests on $50-\mathrm{mm}$ cubic specimen were carried out at the ages of 3, 7, 14, 28, and 56 days according to ASTM C109 (ASTM, 2020). Compressive strength is very important, because it is a major parameter that is considered in a material used for structural components. Prior to the compressive test, the specimens were weighed and measured for determining the unit weight. The compressive strength tests were performed by using 2000-kN compression testing machine (ELE model ADR2000). The specimen was placed on the compressive testing machine and was compressed at the constant rate of $0.9 \mathrm{kN} / \mathrm{s}$ as shown in Figure2 , the maximum load was recorded and the average compressive strength of mortar $\left(f_{m}\right)$ was reported by dividing the maximum load with the area of the loaded surface of triplicate specimens of each mixture proportion.

The splitting tensile strength tests were measured by small cylindrical specimens by adopting the same procedure in accordance with ASTM C496 (ASTM, 2017). Splitting tensile strength test is very important, because it provides the essential data for designing a structure. Generally, the material created from Portland cement will be very vulnerable to tensile cracks, due to various effects and loads imposed. The splitting tensile strength tests were performed at the ages of $3,7,14,28$, and 56 days. Prior to the testing of splitting tensile strength, the length $(L)$ and diameter $(D)$ of specimens were carefully measured. The specimen was placed in the compression testing machine with an aligning jig, as shown in Figure 3.

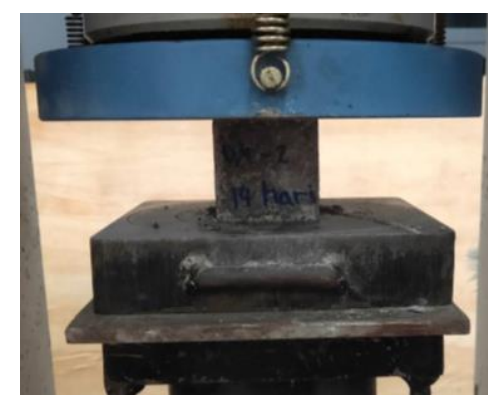

Figure 2. Compressive strength test setup

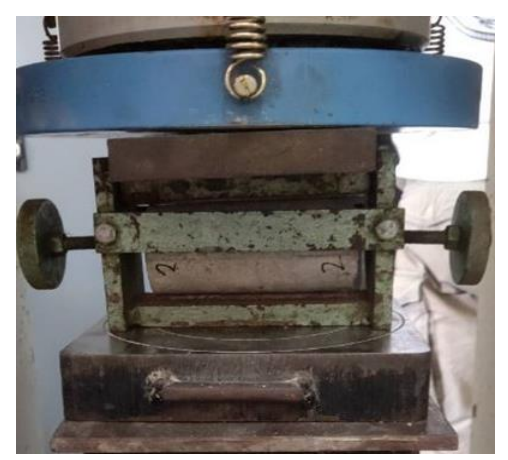

Figure 3. Aligning jig for small mortar cylinder

The stress could be concentrated when the load was applied in the center of specimen, subsequently leading the specimens to split along the longitudinal direction of the specimens. After the peak load $\left(P_{\max }\right)$ was obtained, the splitting tensile strength of mortar $\left(f_{t m}\right)$ was calculated by using $\mathrm{Eq}(1)$.

$$
f_{t m}=2 P_{\max } / \pi L D
$$

The unit weight $(U W)$ of hardened mortar was investigated by dividing the sample mass $(M)$ with its actual volume $(V)$ as demonstrated in Equation (2). The actual volume was obtained by 
multiplying the average value of each dimensions, including width, length, and height.

$$
U W=M / V
$$

\section{Results and Discussion}

\section{Flow and fluidity}

Immediately after mixing, the flow table test was performed for each variation of the mixture. The diameter of fresh mortar along the four lines were measured, then the flow $(F)$ was calculated as the percentage resulting increase the average diameter $\left(D_{\text {avg }}\right)$ of fresh mortar of the base diameter in accordance with ASTM C1437 (ASTM, 2015).

Table 3. Mortar flow

\begin{tabular}{ccc}
\hline Code & $\boldsymbol{D}_{\text {avg }}(\mathbf{m m})$ & $\boldsymbol{F}(\boldsymbol{\%})$ \\
\hline FAM6 & 107.8 & 7.75 \\
FAM8 & 127.8 & 27.75 \\
FAM10 & 117.8 & 17.75 \\
PCM & 206.3 & 106.25 \\
\hline
\end{tabular}

The results of the flow table tests, as shown in Table 3, exhibited that FAM mixtures had a low workability, as evidenced by the value of $7.75 \%$, $27.75 \%$, and $17.75 \%$ in flow test for the mixture of FAM6, FAM8, and FAM10, respectively.

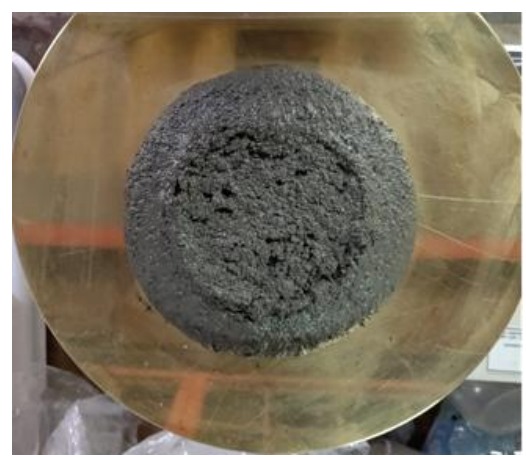

Figure 4. Fluidity of fresh FAM

Figure 4 demonstrated the fluidity of the fresh FAM mixture with $\mathrm{NaOH}$ molarity of $8 \mathrm{M}$. On the other hand, the PCM mixture had better fluidity as indicated by the flow value of $106.25 \%$. Generally, AAM had a lower workability than cement-based mortar because of the presence of silicate in AAM caused a sticky characteristic on the paste (Fang et al., 2018). The trend of the workability results of this research confirmed with experimental data set that has been performed by Malkawi, et al. (Malkawi et al., 2016), that sodium silicate can greatly affect the workability of material due to its high viscosity characteristics. There are several factors that can affect the workability of AAM, including molarity, type of precursor, type of activator, etc.

\section{Mortar unit weight}

The unit weight values of FAM and PCM specimens were investigated at the age of 28 days, as presented in Table 4. The unit weight is an important parameter, which relates to the physical properties of the specimen (Kim et al., 2021). By comparing with the unit weight of PCM, the FAM specimens had relatively greater unit weight about $8.73 \%, 7.21 \%$, and $6.13 \%$ for FAM6, FAM8, and FAM10, respectively. In addition, the higher $\mathrm{NaOH}$ molarity in the alkaline solution used in the FAM, the lower the unit weight value of FAM.

Table 4. Mortar unit weight

\begin{tabular}{lc}
\hline \multicolumn{1}{c}{ Code } & Unit weight $\left(\mathbf{k g} / \mathbf{m}^{\mathbf{3}}\right)$ \\
\hline FAM6 & 2295.06 \\
FAM8 & 2263.07 \\
FAM10 & 2240.19 \\
PCM & 2110.85 \\
\hline
\end{tabular}

\section{Compressive strength}

The development of the average compressive strength for triplicate cubic mortar specimens of each mixture proportion were monitored at the ages of $3,7,14,28$, and 56 days as tabulated in Table 5 . The results of the compressive strength test results of the FAM and PCM specimens were shown in Figure 5.

Table 5. Compressive strength data

\begin{tabular}{ccccc}
\hline \multirow{2}{*}{$\begin{array}{c}\text { Age } \\
\text { (days) }\end{array}$} & \multicolumn{4}{c}{ Mortar compressive strength, $\boldsymbol{f}_{\boldsymbol{m}}$ (MPa) } \\
\cline { 2 - 5 } & FAM6 & FAM8 & FAM10 & PCM \\
\hline 3 & 15.06 & 18.31 & 16.76 & 15.47 \\
7 & 20.01 & 22.43 & 19.64 & 21.08 \\
14 & 23.97 & 25.40 & 25.09 & 33.09 \\
28 & 32.22 & 33.72 & 30.68 & 35.01 \\
56 & 44.16 & 48.33 & 41.03 & 39.85 \\
\hline
\end{tabular}

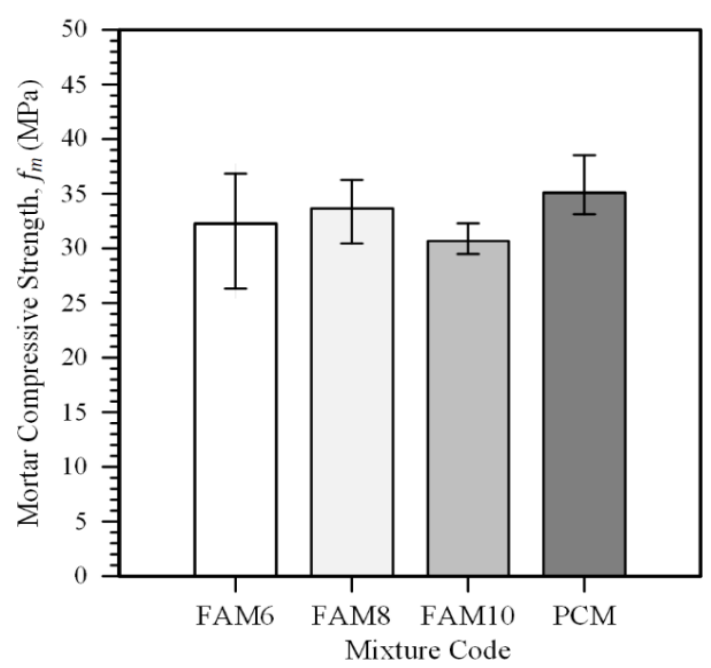

Figure 5. Compressive strength at 28 days 
The $\mathrm{NaOH}$ molarity greatly influenced the compressive strength of FAM specimens. The $\mathrm{NaOH}$ molarity of $8 \mathrm{M}$ reached the optimum compressive strength when comparing with other molarities. At the age of 28 days, FAM 8 mixture had equivalent compressive strength about $3.68 \%$ lower when compared with PCM specimen. It has been confirmed in various other research results, that the compressive strength increases with increasing of $\mathrm{NaOH}$ molarity. However, the compressive strength decreased at higher $\mathrm{NaOH}$ molarity (Huang et al., 2017; Huseien et al., 2018; Zahid et al., 2020). The optimum compressive strength of FAM8 is obtained from the results of both good compaction and reaction of the material. The compaction factor usually associated with the workability of the material. A good reaction in AAM is obtained when the molarity of the activator is sufficient to react with the precursor and solidifies simultaneously. Higher molarity does not mean better, where free alkaline ions can become residues in the structure and can actually reduce the physical properties of the material (Das \& Shrivastava, 2021; Singh \& Subramaniam, 2017)

Based on the compressive strength development up to the age of 56 days, the FAM8 specimen gained significant strength development, and it had higher compressive strength about $21.28 \%$ when compared to the 56-day compressive strength of PCM specimen. Generally, FAM specimens have better development of compressive strength at later age. The compressive strength of FAM8 specimen at 56 days was $43.33 \%$ higher of that at the age of 28 days. On the other hand, the 56-day compressive strength of PCM specimen only increased by about $13.8 \%$ when compared with its compressive strength at 28 days. The condition of the physical properties of AAM is strongly influenced by the reactions that have occurred in the material. In contrast to cement-based material which the evolution of the compressive strength is asymptotic after the age of 28 days. Therefore, the compressive strength growth of AAM is strongly influenced by the type of aluminosilicate and activator used, thus allowing different variations in the increment of compressive strength (Jo et al., 2017; Kuncoro, 2021; McCarthy\& Dyer, 2019).

\section{Splitting tensile strength}

Table 6 showed the splitting tensile strength development which was observed in the ages of 3 , $7,14,28$, and 56 days. The splitting tensile strength at the age of 28 days for FAM and PCM mixtures could be seen in Figure 6.

Consistent with the result of compressive strength, the optimum splitting tensile strength was the mixture with $\mathrm{NaOH}$ molarity of $8 \mathrm{M}$. The FAM8 specimen reached the splitting tensile strength of $2.65 \mathrm{MPa}$ at the age of 28 days. Compared with the splitting tensile strength of the PCM specimen, the FAM8 specimen had a higher value approximately about $19.37 \%$. The 56-day splitting tensile strength of FAM8 specimen lower by $1.87 \%$ when compared with PCM specimen. It can be observed that the specimens based on PCC binder have very different characteristics from the AAM with GFNS binder. This is indicated by the comparison of the development of the splitting tensile strength and the compressive strength for both mixtures.

Table 6. Splitting tensile strength data

\begin{tabular}{ccccc}
\hline \multirow{2}{*}{$\begin{array}{c}\text { Age } \\
\text { (days) }\end{array}$} & \multicolumn{4}{c}{$\begin{array}{c}\text { Mortar splitting tensile stength, } \boldsymbol{f}_{\boldsymbol{t m}} \\
\text { (MPa) }\end{array}$} \\
\cline { 2 - 5 } & FAM6 & FAM8 & FAM 10 & PCM \\
\hline 3 & 1.03 & 0.86 & 1.00 & 1.18 \\
7 & 1.20 & 1.38 & 1.07 & 1.33 \\
14 & 1.61 & 1.97 & 1.74 & 2.05 \\
28 & 2.59 & 2.65 & 2.55 & 2.22 \\
56 & 2.72 & 3.67 & 2.71 & 3.74 \\
\hline
\end{tabular}

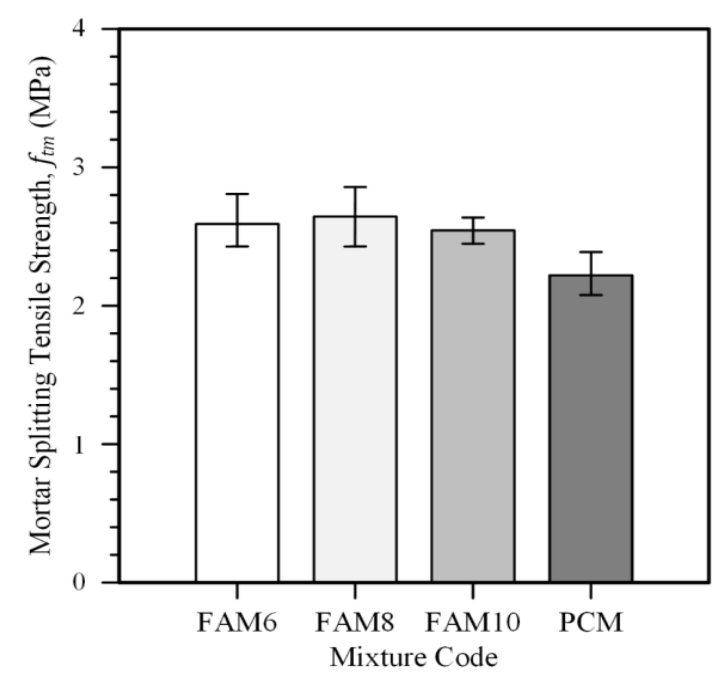

Figure 6. Splitting tensile strength at 28 days

\section{Proposed equations}

In order to evaluate the compressive strength and splitting tensile strength relationship of FAM, the equations were proposed in this study. The 0.5 power law model was a well-established equation for describing the relationship between compressive strength and splitting tensile strength of concrete. The form of 0.5 power law was given in Equation (3) for proposing the correlation between compressive strength $\left(f_{m}\right)$ and splitting tensile strength $\left(f_{t m}\right)$ of mortar with $k$ as the coefficient.

$$
f_{t m}=k \sqrt{f_{m}}
$$


Equations (4), (5), and (6) were proposed for expressing the relationship between compressive strength and splitting tensile strength of FAM with the variations of $\mathrm{NaOH}$ molarity of $6 \mathrm{M}, 8 \mathrm{M}$, and $10 \mathrm{M}$, respectively.

$$
\begin{aligned}
& f_{t m}=0.369 \sqrt{f_{m}} \\
& f_{t m}=0.394 \sqrt{f_{m}} \\
& f_{t m}=0.368 \sqrt{f_{m}} \\
& f_{t m}=0.410 \sqrt{f_{m}}
\end{aligned}
$$

While Equation 7 was proposed for PCM mixture. The experimental data at the ages of $3,7,14,28$, and 56 days were fitted by a 0.5 power law curve, as shown in Figure 7.

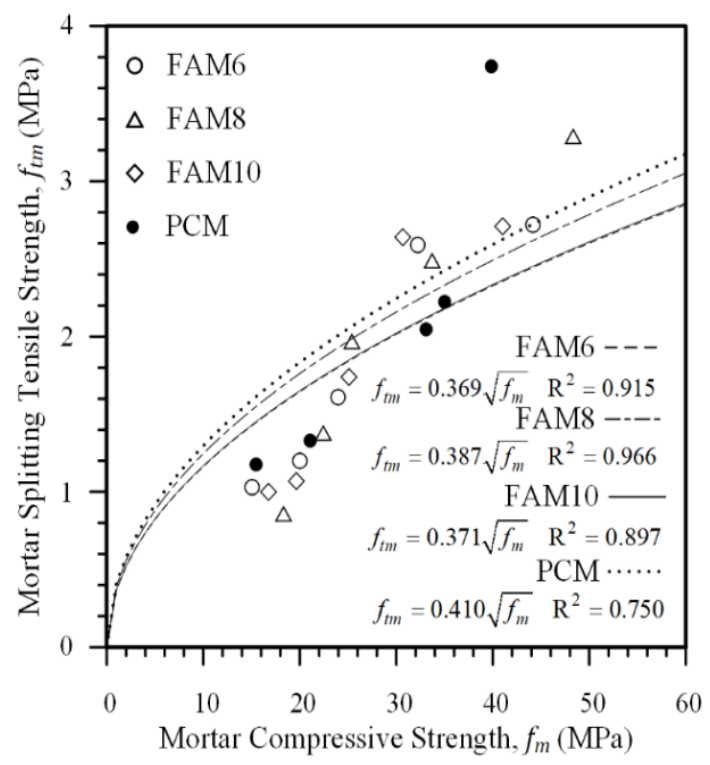

Figure 7. Proposed equations from experimental data

Those equations showed the strong relationship between compressive strength and splitting tensile strength with coefficient of determination $\left(R^{2}\right)$ of $0.915,0.953$, and 0.918 for FAM6, FAM8, and FAM10 mixtures, respectively. While PCM had $R^{2}$ of 0.750 . The $R^{2}$ value of each proposed equation is beyond the value of 0.700 which could be accounted as a high reasonable model (Choi and Yuan, 2005). It is noted that, the PCM mixture had the highest coefficient of 0.410 , while FAM6, FAM8, had coefficient of $0.369,0.387$, and 0.371 , respectively. In addition, the amount of specimens is crucial due to the more experimental data may accommodate improved reability of $f_{m}$ and $f_{t m}$ relationship. Therefore, research extension is required to verify the relationship that obtained in this research.

\section{Visual observations}

The color and visual appearance of the specimen are often used to provide assessment of its performance, such as non-homogeneous matrix, chemical exposure, alkali-silica reaction, etc. Fig. 8(a) exhibited the visual appearance of the FAM specimen while Figure 8(b) is the visual appearance of PCM specimen. It can be observed that the FAM specimens had a darker color when compared with the PCM specimens. This phenomenon is often found in AAM.

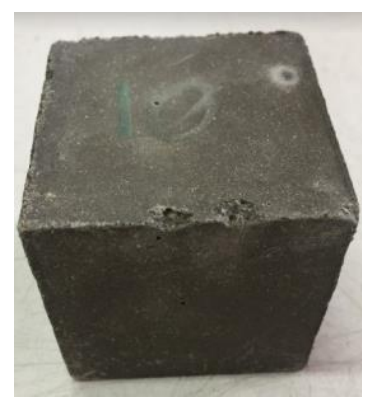

(a) FAM Specimen

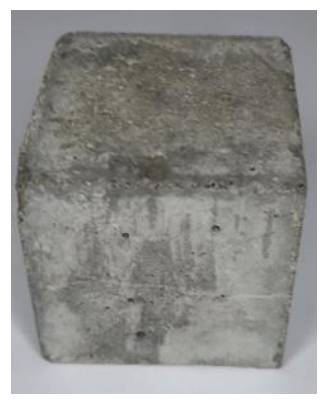

(b) PCM Specimen
Figure 8. The appearance of FAM specimens

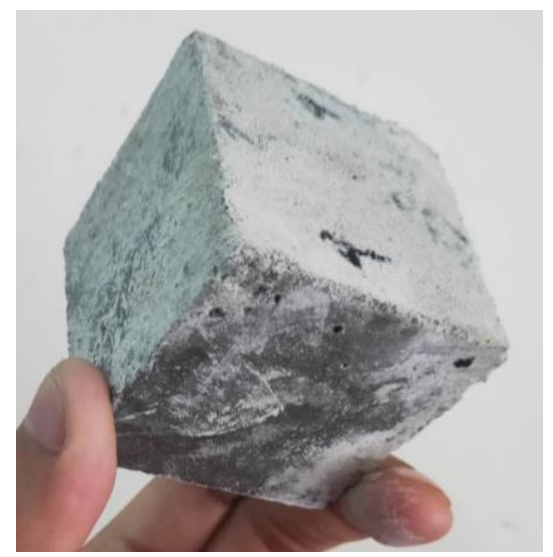

Figure 9. Efflorescence in FAM specimen

However, after 14 days of curing, the FAM specimens began to deposit white salt-like powder on the surface of the specimen, as shown in Figure 9. This phenomenon is often referred to as efflorescence that could be indicated as an unacceptable sign of the specimen and it is frequently encountered in the AAM specimens due to the high alkalinity concentrations used as an activator. So that, the excess alkali ions become residue in the material. Over time, the weak alkaline bonds in the $\mathrm{N}-\mathrm{A}-\mathrm{S}-\mathrm{H}$ gel structure released the excessive unreacted alkaline substances, migrated to the surface of the specimen and reacted with $\mathrm{CO}_{2}$ caused the appearance of white salt-like deposits on the surface of the specimen, which in the long run can cause microcrack (Saludung et al., 2021; Singh \& Subramaniam, 2017; Wang et al., 2020). 


\section{Chemical Reaction of FAM}

AAM achieved by mixing aluminosilicate (material high in content of alumina and silica) with an alkaline activator. The alkali rate and chemical composition of both aluminosilicate and activator play an important role on the reaction and strength development of the material. When mixed, alkaline solutions will release alkaline ions. With curing, the alkaline ions are consumed by pozzolanic reactions resulting in the forming of various natrium silicates, aluminates, and aluminosilicates.

The main products of AAM, which are rich in Si and $\mathrm{Al}$, are N-A-S-H, and C-A-S-H gel. The type of reaction greatly depends on the type of activator used in the material. In this study, the activators used are the source of sodium ions, while the $\mathrm{CaO}$ in GFNS acts as the source of calcium ions, which can react with $\mathrm{Si}$ and $\mathrm{Al}$ and harden. The main reaction products of alkali activated GFNS using sodium hydroxide and sodium silicate could be seen in Equation (8) to (11) (Brouwers and Eijk, 2003; Criado et al., 2016; Sivapullaiah and Moghal, 2011).

$$
\begin{aligned}
& 2 \mathrm{Na}^{+}+\mathrm{S}_{\mathrm{i}} \mathrm{O}_{2}+\mathrm{H}_{2} \mathrm{O} \rightarrow \\
& x \mathrm{Na}_{2} \mathrm{O} \cdot y \mathrm{~S}_{\mathrm{i}} \mathrm{O}_{2} \cdot z \mathrm{H}_{2} \mathrm{O}(\mathrm{N}-\mathrm{S}-\mathrm{H} \text { gel }) \\
& 2 \mathrm{Na}^{+}+\mathrm{Al}_{2} \mathrm{O}_{3}+\mathrm{H}_{2} \mathrm{O} \rightarrow \\
& x \mathrm{Na}_{2} \mathrm{O} \cdot y \mathrm{Al}_{2} \mathrm{O}_{3} \cdot z \mathrm{H}_{2} \mathrm{O}(\mathrm{N}-\mathrm{A}-\mathrm{H} \text { gel }) \\
& 2 \mathrm{Na}^{+}+\mathrm{Al}_{2} \mathrm{O}_{3} / \mathrm{S}_{\mathrm{i}} \mathrm{O}_{2}+\mathrm{H}_{2} \mathrm{O} \rightarrow \\
& x \mathrm{Na}_{2} \mathrm{O} \cdot y \mathrm{Al}_{2} \mathrm{O}_{3} \cdot y \mathrm{~S}_{\mathrm{i}} \mathrm{O}_{2} \cdot z \mathrm{H}_{2} \mathrm{O}(\mathrm{N}-\mathrm{A}-\mathrm{S}-\mathrm{H} \\
& \text { gel }) \\
& \mathrm{Ca}{ }^{2+}+\mathrm{Al}_{2} \mathrm{O}_{3} / \mathrm{S}_{\mathrm{i}} \mathrm{O}_{2}+\mathrm{H}_{2} \mathrm{O} \rightarrow \\
& x 2 \mathrm{CaO} \cdot y \mathrm{Al}_{2} \mathrm{O}_{3} \cdot y \mathrm{~S}_{\mathrm{i}} \mathrm{O}_{2} \cdot z \mathrm{H}_{2} \mathrm{O}(\mathrm{C}-\mathrm{A}-\mathrm{S}-\mathrm{H} \\
& \text { gel })
\end{aligned}
$$

\section{Conclusions}

In this study, GFNS were used to produced AAM mortar activated with sodium hydroxide and sodium silicate. The fresh and hardened properties including workability, compressive strength, and splitting tensile strength were investigated and compared with the equivalent strength of cementbased mortar. Based on the experimental results, the main conclusions can be drawn.

The fresh ferronickel slag alkali activated mortar (FAM) mixtures had lower fluidity when compared with cement-based mortar (PCM) mixture. The result was due to the presence of silicate $(\mathrm{Si})$ element in the GFNS and due to the use of sodium silicate as an alkaline solution. The alkaline solution itself was more viscous than water used in PCM as well as when it reacted with the $\mathrm{Si}$ element in GFNS, it created a sticky consistency. When comparing the silicate content in the FAM and PCM materials, the silicate content in FAM materials is higher, which causes the workability of the material to be lower. The unit weight of FAM specimens in the range between 2240.19 and $2295 \mathrm{~kg} / \mathrm{m}^{3}$, which is higher than that of $2110.85 \mathrm{~kg} / \mathrm{m}^{3}$ of PCM specimen.

The optimum compressive strength of FAM specimens was achieved in a mixture with $\mathrm{NaOH}$ molarity of $8 \mathrm{M}$ (FAM8). At 28 days, the FAM8 specimen had an equivalent compressive strength with that of the PCM specimen, which was approximately $96.8 \%$ of the 28 -day compressive strength of the PCM specimen.

At the later age, the compressive strength of FAM specimens showed a significant increment. At the age of 56 days, the compressive strength of FAM with $\mathrm{NaOH}$ molarity of $6 \mathrm{M}, 8 \mathrm{M}$, and $10 \mathrm{M}$ were $37.06 \%, 43.33 \%$, and $33.74 \%$ higher of that at the age of 28 days. While the increase of PCM specimen was only $13.82 \%$ at the age of 56 days. The compressive strength development of cementbased material is asymptotic after the age of 28 days. In the case of AAM, which is a material whose reaction is based on a pozzolanic reaction, the later age compressive strength is highly dependent on the amount of crystalline phase present in the precursor. In many studies, it is explained that it takes a longer time to gain the optimum compressive strength value of AAM, because it takes time for the crystalline phase to break and react with alkaline ions (Jo et al., 2017).

The splitting tensile strength of FAM specimens with $\mathrm{NaOH}$ molarity of $6 \mathrm{M}, 8 \mathrm{M}$, and $10 \mathrm{M}$ were slight higher about $16.67 \%, 19.37 \%$, and $14.86 \%$, respectively, when compared with the splitting tensile strength of PCM specimens at the age of 28 days.

The relationships between compressive strength and splitting tensile strength of FAM specimens were indicated by the coefficients $(k)$ of 0.369 , 0.394 , and 0.368 , for $\mathrm{NaOH}$ molarity of $6 \mathrm{M}, 8 \mathrm{M}$, and $10 \mathrm{M}$, respectively. While the PCM mixture had the highest coefficient of 0.410 . Comparing with the coefficient of PCM specimen, the coefficient of PCM specimens with $\mathrm{NaOH}$ molarity of $6 \mathrm{M}, 8 \mathrm{M}$, and $10 \mathrm{M}$ were lower by $10.00 \%, 3.90 \%$, and $10.24 \%$, respectively. As the optimum molarity of the FAM mixture is $8 \mathrm{M}$, therefore the proposed equation for FAM8 resulted the highest $f_{t m}$ along with the optimum $f_{m}$. 


\section{Acknowledgment}

The authors would like highly acknowledge the financial aid from Ikatan Alumni Teknik Sipil (IATS) Universitas Katolik Parahyangan through the grant No. 003/IATS-UNPAR/PKS/VII/2017 and ferronickel slag supply from PT. Growth Java Industry with the memorandum of understanding (MoU) No. III/FT-Spl/2019-04/178-MOU.

\section{References}

Alnahhal, M. F., Kim, T., \& Hajimohammadi, A. (2021). Waste-derived activators for alkaliactivated materials: A review. Cement and Concrete Composites, 103980.

ASTM. (2014). ASTM C230/C230M-14. Standard specification for flow table for use in tests of hydraulic cement. West Conshohocken, PA: ASTM International.

ASTM. (2015). ASTM C1437-15. Standard test method for flow of hydraulic cement mortar. West Conshohocken, PA: ASTM International.

ASTM. (2017). ASTM C496 / C496M-17. Standard test method for splitting tensile strength of cylindrical concrete specimens. West Conshohocken, PA: ASTM International.

ASTM. (2020). ASTM C109 / C109M-20b. Standard test method for compressive strength of hydraulic cement mortars (using 2-in. or [50 mm] cube specimens). West Conshohocken, PA: ASTM International.

Brouwers, H. J. H., \& Van Eijk, R. J. (2003, May). Chemical reaction of fly ash. In Proceedings of the 11th International Congress on the Chemistry of Cement (ICCC). The Cement and Concrete Institute of South Africa. Durban, South Africa ,791-800.

Chen, Y., Ji, T., Yang, Z., Zhan, W., \& Zhang, Y. (2020). Sustainable use of ferronickel slag in cementitious composites and the effect on chloride penetration resistance. Construction and Building Materials, 240, 117969.

Choi, Y., \& Yuan, R. L. (2005). Experimental relationship between splitting tensile strength and compressive strength of GFRC and PFRC. Cement and Concrete Research, 35(8), 1587-1591.

Çomak, B., Bideci, A., \& Bideci, Ö. S. (2018). Effects of hemp fibers on characteristics of cement based mortar. Construction and Building Materials, 169, 794-799.
Criado, M., Aperador, W., \& Sobrados, I. (2016). Microstructural and mechanical properties of alkali activated Colombian raw materials. Materials, 9(3), 158 .

Das, S. K., \& Shrivastava, S. (2021). Influence of molarity and alkali mixture ratio on ambient temperature cured waste cement concrete based geopolymer mortar. Construction and Building Materials, 301, 124380 .

Davidovits, J. (2011). Geopolymer chemistry and applications. (3rd edition). Saint-Quentin, France: Geopolymer Institute.

Fang, G., Ho, W. K., Tu, W., \& Zhang, M. (2018). Workability and mechanical properties of alkaliactivated fly ash-slag concrete cured at ambient temperature. Construction and Building Materials, 172, 476-487.

Hewlett, P.C. and Liska M. (2019). Lea's chemistry of cement and concrete (Fifth Edition). MA 02139, United States: Butterworth-Heinemann.

Huang, Y., Wang, Q., \& Shi, M. (2017). Characteristics and reactivity of ferronickel slag powder. Construction and Building Materials, 156, 773-789.

Huseien, G. F., Ismail, M., Khalid, N. H. A., Hussin, M. W., \& Mirza, J. (2018). Compressive strength and microstructure of assorted wastes incorporated geopolymer mortars: Effect of solution molarity. Alexandria engineering journal, 57(4), 3375-3386.

Indonesia, S. N. (2004). Semen portland komposit. SNI 15-7064-2004, ICS 91.10. 10, Badan Standardisasi Nasional, Jakarta.

Jo, B. W., Sikandar, M. A., Chakraborty, S., \& Baloch, Z. (2017). Strength and durability assessment of Portland cement mortars formulated from hydrogen-rich water. Advances in Materials Science and Engineering, 2017, Article ID 2526130 .

Kim, H., Lee, C. H., \& Ann, K. Y. (2019). Feasibility of ferronickel slag powder for cementitious binder in concrete mix. Construction and Building Materials, 207, 693-705.

Kim, Y. H., Kim, H. Y., Yang, K. H., \& Ha, J. S. (2021). Effect of concrete unit weight on the mechanical properties of bottom ash aggregate concrete. Construction and Building Materials, 273, 121998 .

Komnitsas, K., Bartzas, G., Karmali, V., Petrakis, E., Kurylak, W., Pietek, G., \& Kanasiewicz, J. 
(2019). Assessment of alkali activation potential of a Polish ferronickel slag. Sustainability, 11(7), 1863 .

Kuncoro, A. (2021). Influences of FGD gypsum and $\mathrm{CCR}$ on engineering properties of class $\mathrm{F}$ fly ash and GGBFS based alkali-activated material, master thesis, Taiwan: National Taiwan University of Science and Technology.

Kuri, J. C., Khan, M. N. N., \& Sarker, P. K. (2021). Fresh and hardened properties of geopolymer binder using ground high magnesium ferronickel slag with fly ash. Construction and Building Materials, 272, 121877.

Malkawi, A. B., Nuruddin, M. F., Fauzi, A., Almattarneh, H., \& Mohammed, B. S. (2016). Effects of alkaline solution on properties of the HCFA geopolymer mortars. Procedia engineering, 148, 710-717.

Puertas, F., González-Fonteboa, B., GonzálezTaboada, I., Alonso, M. M., Torres-Carrasco, M., Rojo, G., \& Martínez-Abella, F. (2018). Alkaliactivated slag concrete: Fresh and hardened behaviour. Cement and Concrete Composites, 85 , 22-31.

Saha, A. K., Khan, M. N. N., \& Sarker, P. K. (2018). Value added utilization of by-product electric furnace ferronickel slag as construction materials: A review. Resources, Conservation and Recycling, 134, 10-24.

Saludung, A., Azeyanagi, T., Ogawa, Y., \& Kawai, K. (2021). Effect of silica fume on efflorescence formation and alkali leaching of alkali-activated slag. Journal of Cleaner Production, 315, 128210.

Shi, C., Krivenko P.V., and Roy D. (2006). Alkaliactivated cements and concretes. NY 10016, United States: Taylor \& Francis.

Singh, G. B., \& Subramaniam, K. V. (2017). Evaluation of sodium content and sodium hydroxide molarity on compressive strength of alkali activated low-calcium fly ash. Cement and Concrete Composites, 81, 122-132.
Sivapullaiah, P. V., \& Moghal, A. A. B. (2011). Role of gypsum in the strength development of fly ashes with lime. Journal of materials in civil engineering, 23(2), 197-206.

Sugiri, S. (2005). Penggunaan Terak Nikel sebagai Agregat dan Campuran Semen untuk Beton Mutu Tinggi. Jurnal Infrastruktur dan Lingkungan Binaan, I(1), 1-8.

Susanto, D., Djauhari, Z., \& Olivia, M. (2019). Karakteristik Beton Portland Composite Cement (PCC) Dan Silica Fume Untuk Aplikasi Struktur di Daerah Laut. Jurnal Rekayasa Sipil (JRS-Unand), 15(1), 1-11.

Wang, R., \& Meyer, C. (2012). Performance of cement mortar made with recycled high impact polystyrene. Cement and Concrete Composites, 34(9), 975-981.

Wang, Y., Liu, X., Zhang, W., Li, Z., Zhang, Y., Li, Y., \& Ren, Y. (2020). Effects of Si/Al ratio on the efflorescence and properties of fly ash based geopolymer. Journal of Cleaner Production, 244, 118852.

Yan, Z., Sun, Z., Yang, J., Yang, H., Ji, Y., \& Hu, K. (2021). Mechanical performance and reaction mechanism of copper slag activated with sodium silicate or sodium hydroxide. Construction and Building Materials, 266, 120900.

Yang, T. R., Chang, T. P., Chen, B. T., Shih, J. Y., \& Lin, W. L. (2012). Effect of alkaline solutions on engineering properties of alkali-activated GGBFS paste. Journal of Marine Science and Technology, 20(3), 10, 311-318.

Zahid, M., Shafiq N., Razak S.N.A., and Tufail R.F. (2020). Investigating the effects of $\mathrm{NaOH}$ Molarity and the geometry of PVA fibers on the postcracking and the fracture behavior of engineered geopolymer composite. Construction and Building Materials, 265, 120295.

Zhang, P., Gao, Z., Wang, J., Guo, J., Hu, S., \& Ling, Y. (2020). Properties of fresh and hardened fly ash/slag based geopolymer concrete: A review. Journal of Cleaner Production, 270, 122389. 